\title{
ANTIBACTERIAL ACTIVITY OF DIFFERENT TOOTHPASTES AND CHEWING STICKS ON SELECTED BACTERIA ISOLATED FROM THE ORAL CAVITY
}

\section{Anyiam Ifeoma Vivian ${ }^{1}$ and Ariyo Adenike Bosede ${ }^{2}$}

${ }^{1}$ Department of Microbiology, Faculty of Science, Federal University Otuoke, Bayelsa State, Nigeria. E-mail: ifetgod@yahoo.co.uk

${ }^{2}$ Department of Microbiology, Faculty of Science, Federal University Otuoke, Bayelsa State, Nigeria.

\begin{abstract}
Cite this article: Anyiam I.V., Ariyo A.B. (2021), Antibacterial Activity of Different Toothpastes and Chewing Sticks on Selected Bacteria Isolated from the Oral Cavity. African Journal of Environment and Natural Science Research 4(2), 27-38. DOI:

10.52589/AJENSR_S8TKVJ NZ.
\end{abstract}

\section{Manuscript History}

Received: 15 March 2021

Accepted: 10 April 2021

Published: 21 April 2021

Copyright $(\odot 2020$ The Author(s). This is an Open Access article distributed under the terms of Creative Commons AttributionNonCommercialNoDerivatives 4.0 International (CC BY-NC-ND 4.0 ), which permits anyone to share, use, reproduce and redistribute in any medium, provided the original author and source are credited.
ABSTRACT: The present study assessed the antibacterial efficacy of different toothpastes and chewing sticks purchased from a local market in Yenagoa, on selected bacteria isolated from the oral cavity. 100 oral specimens were collected from the primary school pupils of Community Primary School Otuoke, Bayelsa State. The specimens were analyzed by culture, biochemical test and agar well diffusion. Phytochemical and antibacterial properties of ethanol, and aqueous extracts of the chewing sticks were investigated in this study. The bacterial isolates were Escherichia coli, Staphylococcus aureus, Streptococcus mutans and Serratia marcescens. The highest bacterial isolate seen was E. coli, 27 (45\%) while the lowest was Serratia marcescens, 2 (3.3\%). The highest occurring bacterial isolates based on sex was seen in females with $32(53.5 \%)$ while the least in male with $28(46.7 \%)$. The age group with the highest bacterial isolate was 3-6years with $36(60 \%)$ while the least was 11-14yaers with 8 (13.3\%). Preliminary phytochemical screening of the chewing stick extracts revealed the presence of saponins, alkaloids and terpenes in Salvadora persica, and saponins, terpenes and glycosides were present in Massularia acuminata. The toothpastes (Close up and Oral-B) showed antibacterial activity $(p<0.05)$ against all the bacterial isolates; however, no significant activity was observed for Close up on E. coli. The ethanol extracts of both chewing sticks (M. acuminata and $S$. persica) showed antibacterial activity $(p<0.05)$ against the bacterial isolates than the aqueous extracts. However, the aqueous extracts of $S$. persica were shown to be effective against $E$. coli and S. mutans, with inhibition zones of $13.5 \mathrm{~mm}$ at $62.5 \mathrm{mg} / \mathrm{ml}$ concentration and $4.5 \mathrm{~mm}$ at $125 \mathrm{mg} / \mathrm{ml}$ concentration respectively; this showed significant difference $(p<0.05)$, whereas no significant zone of inhibition was observed for $M$. acuminata. In comparison, this study showed Oral-B proved more effective than Close up, while for the chewing sticks, $S$. persica exhibited the greater antibacterial activity. Also, the toothpastes showed more effective antibacterial properties than the chewing sticks.

KEYWORDS: Oral cavity, bacteria, toothpastes, chewing sticks, antibacterial properties. 


\section{INTRODUCTION}

One of the common oral infections suffered by the human population today is dental caries. It is a very harmful disease of the teeth (Moses et al., 2011). It causes decay of the teeth by the degradation of the acids released by the fermentation of the food particles left on the teeth after eating (Silk, 2014). Oral bacteria such Streptococcus mutans, Lactobacillus acidophilus, Staphylococcus aureus, etc. accumulate to form a thick whitish layer on the tooth known as dental plaque, by combining with the food remains and saliva (Marsh et al., 2011). The organism produces acid from the fermented foods which causes destruction of the tooth surface and form holes and cavities in the teeth (Verkaik et al., 2011).

One of the major factors contributing to tooth decay is poor oral hygiene due to lack of proper understanding of dental caries, which has led to a rise in the prevalence of dental caries around the world. Its treatment is expensive and requires the competence of highly skilled professionals (Tonetti et al., 2015). In developing countries where there is a lack of dental care facilities for most people, it is important to educate them on dental care to promote traditional means of teeth cleaning in addition to conventional toothpastes. Toothpaste, as an abrasive, is used to promote oral health, help in removing dental plaque and food debris from the teeth, suppresses halitosis, and the active ingredients (fluoride) helps to prevent tooth decay and gum disease known as gingivitis (American Dental Association, 2010).

Although, before the use of toothpaste, early man was known to use miswak as natural hygiene tools for oral health. However, various studies have been carried out to explain the general effect of miswak on oral health, and equally elucidate certain natural chemical compounds contained in miswak which play important roles in maintaining good hygiene (Al-Bayati et al., 2018). Currently, miswak extract is now incorporated in toothpaste as both an active ingredient and as flavoring (Sudhir et al., 2018). Thus, this study is set to determine the efficacy of different toothpastes and chewing sticks, and to determine their antibacterial activities on selected bacteria isolated from the oral cavity as a way of preventing dental caries.

\section{LITERATURE REVIEW}

Toothpaste is a gel dentifrice for cleaning and maintaining the beauty and health of teeth, and to promote oral hygiene. Toothpaste as an abrasive aid in removing dental plaque and food from the teeth, helps in suppressing foul-smelling breath to help prevent tooth decay and gum disease (American Dental Association, 2010). However large amounts of swallowed toothpaste while bushing can be toxic to humans (National Library of Medicine "Toothpaste overdose", 2014). Toothpaste contains $20 \%-42 \%$ water, and is derived from various components which include mainly abrasives, fluoride and detergents (Hujoel et al., 2019). These soluble particles are designed to help remove plaque and calculus from the teeth to prevent the accumulation of tartar and reduce cavities and periodontal disease (Hujeol, 2019). Furthermore, this gel dentifrice also contains antimicrobial agents like triclosan (Riley and Lamont, 2013), although clinical trials have shown the use of high fluoride dentifrices (Walsh et al., 2019) to reduce the amount of plaque accumulated and decrease the number of Streptococcus mutans and Lactobacilli (Ekstrand, 2016).

Chewing sticks are twigs or roots of certain plants that are chewed till one end becomes frayed. The end can be used to brush against the teeth (Panati, 2013), while the other end can be used 
as a toothpick (Zheng et al., 2013). Most common plants used as chewing sticks have high contents of tannins (astringent and antibacterial) or other compounds which benefit healthy gums and teeth (Shetty et al., 2010). The purpose of oral hygiene-using toothpaste and chewing sticks - is to efficiently reduce oral bacterial flora and promote dental health (America Dental Association, 2010).

\section{MATERIALS AND METHODS}

Two brands of toothpastes were purchased from a local market (Swali market) in Yenagoa, Bayelsa State, South-South Nigeria. Their batch numbers, registration numbers, manufacture and expiry dates as well as the presence of the manufacturer's seal were taken note off. Two different chewing sticks (Massularia acuminata and Salvadora persica) were also purchased from the same market.

\section{Specimen Collection, Processing and Identification}

A hundred oral specimens were collected from primary school pupils of Community Primary School, Otuoke, Bayelsa state. Consent was given by the school management. The specimens were cultured on blood agar, chocolate agar, MacConkey agar, CLED agar and nutrient agar. After 24 hours of incubation at $37^{\circ} \mathrm{C}$, the isolates were checked for growth. Pure isolates obtained were characterized using gram staining technique and biochemical tests which include catalase, oxiadase and coagulase. Haemolysis test was also carried out.

\section{Preparation of Chewing Stick Extracts and Toothpaste Solution}

500g of Salvadora persica and Massularia acuminata chewing sticks were cut into pieces and ground into powder with a commercially available food blender. $100 \mathrm{ml}$ of $95 \%$ ethanol and sterile water was added to $10 \mathrm{~g}$ of the powder in a sterile well capped flask, left for 7 days at room temperature and then filtered using number 1 Whatman filter paper. The extract then evaporated in a mantle heater at $40^{\circ} \mathrm{C}$ until ethanol was removed while the aqueous extract was centrifuged at 2000pm for 10 minutes (Al-lafi and Abadueh, 1995). The supernatant was passed through a $0.45 \mathrm{~mm}$ membrane filter. The extracts were preserved in sterile screw-capped vials in the refrigerator for further use (Al-koubaisi, 2001).

The different toothpaste solutions were made by mixing the calculated amount of toothpaste $(2 \mathrm{~g})$ in measured volume $(2 \mathrm{ml})$ of sterile pyrogen-free distilled water to give 1:1 dilution; they were further diluted in sterile water and three different dilutions of 1:2, 1:4 and 1:8 were made.

\section{Phytochemical Analysis}

Phytochemical screening were carried out on the two different chewing sticks Salvadora persica (Miswak) and Massularia acuminata (Pako Ijebu) to determine the presence of the following constituents: flavonoids, tannins, saponins, terpenes, basic alkaloids and glycosides, using the method described by Sony et al. (2011) and Thilagavati et al. (2015).

\section{In-vitro Antibacterial Sensitivity Testing}

The toothpastes and chewing sticks were tested on the isolates to determine their efficacy at various concentrations. 


\section{Preparation of Concentration for the Chewing Stick Extract}

$2 \mathrm{ml}$ of the plant extract was measured using a $2 \mathrm{ml}$ syringe and was transferred into a test tube containing $2 \mathrm{ml}$ of $70 \%$ dimethyl sulfoxide (DMSO) to give a concentration of $500 \mu \mathrm{g} / \mathrm{ml}$; they were further diluted in $70 \%$ DMSO to give three different concentrations of 250,125 and $62.5 \mathrm{mg} / \mathrm{ml}$ respectively.

\section{Preparation of McFarland Standard}

A $0.5 \mathrm{McFarland}$ standard was prepared by mixing $0.05 \mathrm{ml}$ of barium chloride dihydrate, with $9.95 \mathrm{ml}$ of $1 \%$ sulfuric acid (Cockerill et al., 2012). The standard was compared visually to a suspension of bacteria in sterile saline.

\section{Antibacterial Assay}

The antibacterial assay was determined using modified agar well diffusion. This method was carried out by streaking a loopful of each of the test isolates onto a prepared nutrient agar plate. A sterile $8 \mathrm{~mm}$ cork-borer was used to cut one central and four wells at equidistance in each of the plates. $0.2 \mathrm{ml}$ of the toothpastes dilutions was introduced into each of the four wells while the same amount of sterile pyrogen-free water was introduced into the first well (central) as control. This method was repeated for the chewing extracts with the same volume of $70 \%$ DMSO serving as control in this case, and the plates were allowed to stay on a horizontal surface for one hour to enable the substances to diffuse before incubating at $37^{\circ} \mathrm{C}$ for 24 hours. Zones of inhibition were measured in $\mathrm{mm}$ after incubation to determine the antibacterial efficacy. All experiments were performed in duplicate (Sarmad, 2013).

\section{Statistical Analysis}

The data were analysed using Anova IBM® SPSS $®$ statistics version 21 . One-way ANOVA was used to compare the mean value of the outcome variable followed by post hoc test. The significance level was set at $\mathrm{p}<0.05$.

\section{RESULTS}

Table 1 shows the distribution of bacterial isolates based on sex. Out of the one hundred (100) specimens examined, a total of 60 isolates were obtained - 28 from males and 32 from females. The frequency of bacteria isolated were Escherichia coli, 27 (45\%); Staphylococcus aureus, 21 (35\%); Streptococcus mutans, 10 (16.7\%); and Serratia marsescens, 2 (3.3\%).

Table 2 shows the frequency distribution of bacterial isolates based on age. Of the sixty bacterial isolates, 36 were obtained from pupils between the ages 3-6 years, 16 from 7-10 years and eight from 11-14 years. The highest number of isolates was E. coli with $20(33.3 \%)$ as seen between the age 3-6 years while the least was $1(1.7 \%)$ for $S$. mutans, as seen between the 3-6 years and $S$. marsescens between the ages 7-10 years and 11-14 years respectively.

The phytochemical constituents of Massularia acuminate and Salvadora persica, which showed the presence of saponins and terpenes in both plant extracts, was seen in relative abundance. However, the concentration of saponin was higher in M. acuminata while S. persica had higher concentration of terpenes. Alkaloids were present in S. persica only, while 
glycosides were seen in $M$. acuminata only. Flavonoids were absent in both extracts as shown in Table 3.

Table 4 shows the mean zone of inhibition $(\mathrm{mm})$ of toothpastes on bacterial isolates at various concentrations. The result showed that Oral-B was more effective with a zone of inhibition of $19.5 \mathrm{~mm}$ for $E$. coli while there was no significant zone of inhibition $(0 \mathrm{~mm})$ for Close up.

Oral-B exhibited greater efficacy against $S$. aureus with a zone of inhibition of $15.5 \mathrm{~mm}$ than Close up with $5.5 \mathrm{~mm}$. However, both dentifrices showed a level of significance $(\mathrm{p}<0.05)$ at all concentrations.

Close up showed greater effectiveness against $S$. mutans with a zone of inhibition at $18.5 \mathrm{~mm}$ while Oral-B at $18 \mathrm{~mm}$. There was significant difference at $\mathrm{p}<0.05$ in all the concentrations.

The mean zone of inhibition of toothpastes on S. marcescens showed that Close up exhibited greater efficacy at $19.5 \mathrm{~mm}$ than Oral-B at $14.5 \mathrm{~mm}$. At a significance level of $\mathrm{p}<0.05$, all concentrations of both toothpastes were significant.

The mean zone of inhibition of the various chewing stick extracts on $E$. coli at various concentrations is shown in Table 5. The ethanol extract of both chewing sticks showed antibacterial properties with a mean zone ranging from $18.5 \mathrm{~mm}-15.5 \mathrm{~mm}$ and $10.5 \mathrm{~mm}-4.0 \mathrm{~mm}$ for S. persica and M. acuminata respectively. The largest zone of inhibition was observed at a concentration of $125 \mathrm{mg} / \mathrm{ml}$ for S. persica, while observed at $500 \mathrm{mg} / \mathrm{ml}$ for M. acuminata in which efficacy decreased as concentration decreased. However, the aqueous extract exhibited antibacterial properties at the concentration of $62.5 \mathrm{mg} / \mathrm{ml}$ for $S$. persica while there was no significant zone of inhibition by $M$. acuminata at $\mathrm{p}<0.05$. The aqueous extract of $S$. persica exhibited more antibacterial properties as the concentration decreased.

The result of the mean zone of inhibition of various chewing stick extracts on S. aureus at various concentrations is shown in Table 6. For $S$. persica, the ethanol extract produced a mean zone range of $13.5 \mathrm{~mm}-11.0 \mathrm{~mm}$, and $6.5 \mathrm{~mm}-4.0 \mathrm{~mm}$ for $M$. acuminata. Whereas, the aqueous extracts of both chewing sticks exhibited no antibacterial properties against $S$. aureus. The largest zone of inhibition was seen with both ethanol extracts at a concentration of $125 \mathrm{mg} / \mathrm{ml}$ for $S$. persica and $500 \mathrm{mg} / \mathrm{ml}$ for M. acuminata.

Table 7 shows the mean zone of inhibition of various chewing sticks on $S$. mutans at various concentrations. The result showed the ethanol extract of $M$. acuminata exhibited greater efficacy with a mean zone range of $10.0 \mathrm{~mm}-4.0 \mathrm{~mm}$ than $S$. persica with a mean zone range of $9.0 \mathrm{~mm}-7.5 \mathrm{~mm}$. For the aqueous extract, the efficacy was from $4.5 \mathrm{~mm}-2.5 \mathrm{~mm}$ for $S$. persica. The largest zone of inhibition for $S$. persica and $M$. acuminata was seen at $125 \mathrm{mg} / \mathrm{ml}$ and $500 \mathrm{mg} / \mathrm{ml}$ respectively, with ethanol extracts, while for aqueous extract of $S$. persica at $125 \mathrm{mg} / \mathrm{ml}, M$. acuminata exhibited no significant zone of inhibition at $\mathrm{p}<0.05$ significance level.

Table 8 shows the mean zone of inhibition of various chewing sticks on $S$. marcescens. The ethanol extracts of $S$. persica and $M$. acuminata exhibited antibacterial properties with the largest zone at a concentrations of $62.5 \mathrm{mg} / \mathrm{ml}$ and $500 \mathrm{mg} / \mathrm{ml}$ respectively. However, the aqueous extracts of both chewing sticks exhibited no significant zone of inhibition at $p<0.05$. 
African Journal of Environment and Natural Science Research

ISSN: 2689-9434

Volume 4, Issue 2, 2021 (pp. 27-38)

www.abjournals.org

Table 1: Distribution of bacterial isolates based on sex

\begin{tabular}{lcccc}
\hline Isolates & $\begin{array}{c}\text { Number } \\
\text { of isolates }\end{array}$ & Male & Female & Total (\%) \\
\hline Escherichia coli & 27 & $13(21.7 \%)$ & $14(23.3 \%)$ & $27(45.0 \%)$ \\
Staphylococcus aureus & 21 & $11(18.3 \%)$ & $10(16.7 \%)$ & $21(35.0 \%)$ \\
Streptococcus mutans & 10 & $3(5.0 \%)$ & $7(11.7 \%)$ & $10(16.7 \%)$ \\
Serratia marsescens & 2 & $1(1.7 \%)$ & $1(1.7 \%)$ & $2(3.3 \%)$ \\
Total & 60 & $28(46.7)$ & $32(53.4)$ & $60(100 \%)$ \\
\hline
\end{tabular}

Experiments were done in duplicates $\pm S . D$ of two replicates

Table 2: Frequency distribution of bacterial isolates based on age

\begin{tabular}{lllllr}
\hline Age Interval & Escherichia coli & S. aureus & S. mutans & S. marsescens & Total (Years) \\
\hline $3-6$ & $20(33.3 \%)$ & $15(25.0 \%)$ & $1(1.7 \%)$ & $0(0 \%)$ & $36(60 \%)$ \\
$7-10$ & $5(8.3 \%)$ & $3(5.0 \%)$ & $7(11.7 \%)$ & $1(1.7 \%)$ & $16(26.7 \%)$ \\
$11-14$ & $2(3.3 \%)$ & $3(5.0 \%)$ & $2(3.3 \%)$ & $1(1.7 \%)$ & $8(13.3 \%)$ \\
Total & $27(44.9 \%)$ & $21(35.0 \%)$ & $10(16.7 \%)$ & $2(3.4 \%)$ & $60(100 \%)$ \\
\hline
\end{tabular}

Experiments were done in duplicates \pm S.D of two replicates

Key:

S. aureus $=$ Staphylococcus aureus

S. mutans $=$ Streptococcus mutans

S. marcescens $=$ Serratia marcescens

Table 3: Phytochemical analysis

\begin{tabular}{lcc}
\hline Phytochemicals & Salvadora persica & Massularia acuminata \\
\hline Flavonoids & - & - \\
Saponins & ++ & +++ \\
Tannins & - & - \\
Alkaloids & + & - \\
Reducing sugars & - & + \\
Terpenes & ++ & + \\
\hline
\end{tabular}

Key:

$+++=$ Highly present

$++=$ Moderately present

$+=$ Slightly present

- = Absent 
Table 4: Mean zones of inhibition $(\mathrm{mm})$ of toothpastes on bacterial isolates

\begin{tabular}{|c|c|c|c|c|c|c|}
\hline & & & Concen & tration & & \\
\hline Isolates & & Toothpaste & $1: 1$ & $1: 2$ & $1: 4$ & $1: 8$ \\
\hline E. coli & & Close up & $0.00 \pm 0.00$ & $0.00 \pm 0.00$ & $0.00 \pm 0.00$ & $0.00 \pm 0.00$ \\
\hline & & Oral B & $19.5 \pm 1.41$ & $14.0 \pm 2.83$ & $8.5 \pm 0.71$ & $0.00 \pm 0.00$ \\
\hline S. aurel & & Close up & $5.5 \pm 0.71$ & $0.00 \pm 0.00$ & $0.00 \pm 0.00$ & $0.00 \pm 0.00$ \\
\hline Oral B & & $15.5 \pm 2.12$ & $13.0 \pm 1.41$ & $5.0 \pm 0.00$ & $0.00 \pm 0.00$ & \\
\hline Streptoc & occus & Close up & $18.5 \pm 0.71$ & $11.5 \pm 0.71$ & $8.5 \pm 0.71$ & $5.0 \pm 0.00$ \\
\hline mutans & & Oral B & $18.0 \pm 1.4$ & $10.0 \pm 0.00$ & $7.0 \pm 0.00$ & $0.00 \pm 0.00$ \\
\hline Serratic & & Close up & $19.5 \pm 0.71$ & $12.5 \pm 0.71$ & $0.00 \pm 0.00$ & $0.00 \pm 0.00$ \\
\hline marcesc & ens & Oral B & $14.5 \pm 0.71$ & $10.5 \pm 0.71$ & $9.5 \pm 0.71$ & $0.00 \pm 0.00$ \\
\hline Control & & & $0.00 \pm 0.00$ & $0.00 \pm 0.00$ & $0.00 \pm 0.00$ & $0.00 \pm 0.00$ \\
\hline Control & & & $0.00 \pm 0.00$ & $0.00 \pm 0.00$ & $0.00 \pm 0.00$ & $0.00 \pm 0.00$ \\
\hline Values & re me & an inhibition $\mathrm{z}$ & he $(\mathrm{mm}) \pm$ S.D & of two replic & cates & \\
\hline $\begin{array}{l}\text { Key: } \\
\text { Control } \\
\text { Control }\end{array}$ & $\begin{array}{l}A=C \\
B=C\end{array}$ & $\begin{array}{l}\text { Ontrol for Clo } \\
\text { ontrol for Ora }\end{array}$ & & & & \\
\hline Table 5 & ean & zone of inhi & $(\mathrm{mm})$ of & ving stic & tracts on Esc & hia coli \\
\hline Dilution & & $500 \mathrm{mg} / \mathrm{ml}$ & $250 \mathrm{mg} / \mathrm{m}$ & & $125 \mathrm{mg} / \mathrm{ml}$ & $62.5 \mathrm{mg} / \mathrm{ml}$ \\
\hline ASP & 0.00 & $0 \pm 0.00$ & $0.00 \pm 0.0 \mathrm{C}$ & & $10.0 \pm 1.4$ & $13.5 \pm 0.71$ \\
\hline ESP & 0.00 & $0 \pm 0.00$ & $16.0 \pm 1.41$ & & $18.5 \pm 0.71$ & $15.5 \pm 0.71$ \\
\hline AMA & 0.00 & $0 \pm 0.00$ & $0.00 \pm 0.00$ & & $0.00 \pm 0.00$ & $0.00 \pm 0.00$ \\
\hline EMA & 10.5 & $5 \pm 0.71$ & $8.0 \pm 0.00$ & & $4.0 \pm 0.00$ & $0.00 \pm 0.00$ \\
\hline cASP & 0.00 & $0 \pm 0.00$ & $0.00 \pm 0.00$ & & $0.00 \pm 0.00$ & $0.00 \pm 0.00$ \\
\hline cESP & 0.00 & \pm 0.00 & $0.00 \pm 0.00$ & & $0.00 \pm 0.00$ & $0.00 \pm 0.00$ \\
\hline cAMA & 0.00 & \pm 0.00 & $0.00 \pm 0.00$ & & $0.00 \pm 0.00$ & $0.00 \pm 0.00$ \\
\hline cEMA & 0.00 & $0 \pm 0.00$ & $0.00 \pm 0.00$ & & $0.00 \pm 0.00$ & $0.00 \pm 0.00$ \\
\hline
\end{tabular}

Values are mean inhibition zone $(\mathrm{mm}) \pm$ S.D of two replicates

Key:

ASP $=$ Aqueous extract of Salvadora persica

$\mathrm{ESP}=$ Ethanol extract of salvadora persica

cASP $=$ Control for aqueous extract of salvadora persica

$\mathrm{cESP}=$ Control for ethanol extract of salvadora persica

AMA = Aqueous extract of Massularia acuminata

EMA = Ethanol extract of Massularia acuminata

cAMA = Control for aqueous extract of Massularia acuminata

cEMA $=$ Control for ethanol extract of Massularia acuminata 
Table 6: Mean zones of inhibition (mm) of chewing stick extracts on Staphylococcus aureus

\begin{tabular}{lllll}
\hline Dilution & $500 \mathrm{mg} / \mathrm{ml}$ & $250 \mathrm{mg} / \mathrm{ml}$ & $125 \mathrm{mg} / \mathrm{ml}$ & $62.5 \mathrm{mg} / \mathrm{ml}$ \\
\hline ASP & $0.00 \pm 0.00$ & $0.00 \pm 0.00$ & $0.00 \pm 0.00$ & $0.00 \pm 0.00$ \\
ESP & $0.00 \pm 0.00$ & $8.5 \pm 2.12$ & $13.5 \pm 2.12$ & $11.0 \pm 1.41$ \\
AMA & $0.00 \pm 0.00$ & $0.00 \pm 0.00$ & $0.00 \pm 0.00$ & $0.00 \pm 0.00$ \\
EMA & $6.5 \pm 0.71$ & $5.5 \pm 0.71$ & $4.0 \pm 0.00$ & $0.00 \pm 0.00$ \\
cASP & $0.00 \pm 0.00$ & $0.00 \pm 0.00$ & $0.00 \pm 0.00$ & $0.00 \pm 0.00$ \\
cESP & $0.00 \pm 0.00$ & $0.00 \pm 0.00$ & $0.00 \pm 0.00$ & $0.00 \pm 0.00$ \\
cAMA & $0.00 \pm 0.00$ & $0.00 \pm 0.00$ & $0.00 \pm 0.00$ & $0.00 \pm 0.00$ \\
cEMA & $0.00 \pm 0.00$ & $0.00 \pm 0.00$ & $0.00 \pm 0.00$ & $0.00 \pm 0.00$ \\
\hline
\end{tabular}

Values are mean inhibition zones $(\mathrm{mm}) \pm$ S.D of two replicates

Key:

ASP $=$ Aqueous extract of Salvadora persica

$\mathrm{ESP}=$ Ethanol extract of salvadora persica

$\mathrm{cASP}=$ Control for aqueous extract of salvadora persica

cESP $=$ Control for ethanol extract of salvadora persica

AMA = Aqueous extract of Massularia acuminata

EMA = Ethanol extract of Massularia acuminata

cAMA = Control for aqueous extract of Massularia acuminata

cEMA $=$ Control for ethanol extract of Massularia acuminata

Table 7: Mean zones of inhibition (mm) of chewing stick extracts on Streptococcus mutans

\begin{tabular}{llllc}
\hline Dilution & $500 \mathrm{mg} / \mathrm{ml}$ & $250 \mathrm{mg} / \mathrm{ml}$ & $125 \mathrm{mg} / \mathrm{ml}$ & $62.5 \mathrm{mg} / \mathrm{ml}$ \\
\hline ASP & $3.00 \pm 0.00$ & $3.5 \pm 0.00$ & $4.5 \pm 0.71$ & $2.5 \pm 0.71$ \\
ESP & $0.00 \pm 0.00$ & $7.5 \pm 0.71$ & $9.0 \pm 0.00$ & $7.5 .0 \pm 0.71$ \\
AMA & $0.00 \pm 0.00$ & $0.00 \pm 0.00$ & $0.00 \pm 0.00$ & $0.00 \pm 0.00$ \\
EMA & $10.0 \pm 0.00$ & $8.5 \pm 0.71$ & $7.0 \pm 0.00$ & $4.00 \pm 0.00$ \\
cASP & $0.00 \pm 0.00$ & $0.00 \pm 0.00$ & $0.00 \pm 0.00$ & $0.00 \pm 0.00$ \\
cESP & $0.00 \pm 0.00$ & $0.00 \pm 0.00$ & $0.00 \pm 0.00$ & $0.00 \pm 0.00$ \\
cAMA & $0.00 \pm 0.00$ & $0.00 \pm 0.00$ & $0.00 \pm 0.00$ & $0.00 \pm 0.00$ \\
cEMA & $0.00 \pm 0.00$ & $0.00 \pm 0.00$ & $0.00 \pm 0.00$ & $0.00 \pm 0.00$ \\
\hline
\end{tabular}

Values are mean inhibition zones $(\mathrm{mm}) \pm$ S.D of two replicates

Key:

ASP $=$ Aqueous extract of Salvadora persica

$\mathrm{ESP}=$ Ethanol extract of salvadora persica

$\mathrm{cASP}=$ Control for aqueous extract of salvadora persica

$\mathrm{cESP}=$ Control for ethanol extract of salvadora persica

AMA = Aqueous extract of Massularia acuminata

EMA = Ethanol extract of Massularia acuminata

cAMA = Control for aqueous extract of Massularia acuminata

cEMA = Control for ethanol extract of Massularia acuminata 
African Journal of Environment and Natural Science Research

ISSN: 2689-9434

Volume 4, Issue 2, 2021 (pp. 27-38)

www.abjournals.org

Table 8: Mean zones of inhibition ( $\mathrm{mm}$ ) of chewing stick extracts on Serratia marcescens

\begin{tabular}{|c|c|c|c|c|}
\hline Dilution & $500 \mathrm{mg} / \mathrm{ml}$ & $250 \mathrm{mg} / \mathrm{ml}$ & $125 \mathrm{mg} / \mathrm{ml}$ & $62.5 \mathrm{mg} / \mathrm{ml}$ \\
\hline ASP & $0.00 \pm 0.00$ & $0.00 \pm 0.00$ & $0.00 \pm 0.00$ & $0.00 \pm 0.00$ \\
\hline ESP & $0.00 \pm 0.00$ & \multirow{2}{*}{\multicolumn{2}{|c|}{$3.5 \pm 0.71$}} & $10.0 \pm 1.41$ \\
\hline \multicolumn{3}{|c|}{$11.0 \pm 1.41$} & & \\
\hline AMA & $0.00 \pm 0.00$ & $0.00 \pm 0.00$ & $0.00 \pm 0.00$ & $0.00 \pm 0.00$ \\
\hline EMA & $5.50 . \pm 0.71$ & $0.00 \pm 0.00$ & $0.00 \pm 0.00$ & $0.00 \pm 0.00$ \\
\hline cASP & $0.00 \pm 0.00$ & $0.00 \pm 0.00$ & $0.00 \pm 0.00$ & $0.00 \pm 0.00$ \\
\hline cESP & $0.00 \pm 0.00$ & $0.00 \pm 0.00$ & $0.00 \pm 0.00$ & $0.00 \pm 0.00$ \\
\hline cAMA & $0.00 \pm 0.00$ & $0.00 \pm 0.00$ & $0.00 \pm 0.00$ & $0.00 \pm 0.00$ \\
\hline cEMA & $0.00 \pm 0.00$ & $0.00 \pm 0.00$ & $0.00 \pm 0.00$ & $0.00 \pm 0.00$ \\
\hline
\end{tabular}

Values are mean inhibition zones $(\mathrm{mm}) \pm \mathrm{S} . \mathrm{D}$ of two replicates

Key:

ASP $=$ Aqueous extract of Salvadora persica

$\mathrm{ESP}=$ Ethanol extract of salvadora persica

cASP $=$ Control for aqueous extract of salvadora persica

$\mathrm{cESP}=\mathrm{Control}$ for ethanol extract of salvadora persica

AMA = Aqueous extract of Massularia acuminata

EMA = Ethanol extract of Massularia acuminata

cAMA $=$ Control for aqueous extract of Massularia acuminata

cEMA = Control for ethanol extract of Massularia acuminate

\section{DISCUSSION}

In this study, both gram negative and gram-positive bacteria were subjected to different toothpastes (Close up and Oral-B) and chewing sticks (Salvadora persica and Massularia acumunata) to test for their efficacy. The result of the current research clearly showed that the chewing sticks and the toothpastes inhibited the growth of bacteria causing tooth decay. However, the range of effectiveness is concentration-dependent and varied against the different tested bacteria (Sudhir et al., 2018). The bacterial isolates seen were Escherichia coli, S. aureus, $S$. mutans and $S$. marcescens. The presence of these bacteria shows they are pathogenic and could be responsible for oral diseases (Anyiam et al., 2016). The highest occurring bacterial isolate was $E$. coli with 27 (45.0\%) while the lowest was $S$. marcescens with 2 (3.3\%). The age group seen with the highest bacterial isolates was 3-6 years with $36(60 \%)$, while the least was ages $11-14$ years with $8(13.3 \%)$. This could be as a result of exposure to different diets and lack of good oral hygiene practices.

The findings from this study revealed the presence of alkaloids, saponins, terpenes, and the absence of flavonoids and tannins in the extracts. The efficacy of the plant materials could be as a result of the presence of some basic phytochemicals such as saponins and terpenes in both extracts, and the presence of glycosides and alkaloids in $M$. acumunata and $S$. persica respectively. In comparison, the extracts of $S$. persica exhibited greater antibacterial properties than $M$. acuminata. This could be due to the absence of alkaloids in $M$. acuminata which are known to exhibit antibacterial properties (Rao et al., 2000). 
The evaluation of the antibacterial properties of extracts on bacterial isolates showed they all possess antibacterial properties. The antibacterial activity was seen at varying concentrations indicating that the chewing stick extract had a broad antibacterial spectrum.

The aqueous extract of both chewing sticks exhibited no antibacterial properties against $S$. aureus. This result agrees with a similar work done by Naziru et al., (2015) who compared the antibacterial activity of chewing sticks and toothpastes commonly used in Kano (Nigeria) on Staphylococcus and Streptococcus spp. However, the aqueous extract of $S$. persica exhibited significant antibacterial properties at $\mathrm{p}<0.05$ on $E$. coli and $S$. mutans (only at a concentration of $125 \mathrm{mg} / \mathrm{ml}$ and $62.5 \mathrm{mg} / \mathrm{l}$ respectively), which seems to agree with the findings of Sarmad, (2013) who revealed that the aqueous extract of $S$. persica showed antibacterial properties against many cariogenic bacteria including $E$. coli and $S$. mutans. There was no significant zone of inhibition for M. acuminata on all the bacterial isolates.

The ethanol extracts of the chewing sticks showed greater inhibitory effect than aqueous extracts; this is in accordance with the research carried out by Odeleye et al., (2016). The aqueous extracts of the chewing stick showed a very poor inhibitory activity against the bacterial isolates. This may be due to the poor solubility nature of the active principles of the plant material.

Of the toothpastes used, Oral-B proved to be more efficacious (based on mean zone of inhibition) than Close up; this is in agreement with the research carried out by Josephs et al., (2016) on the evaluation of antibacterial activity of toothpastes on some selected microorganisms.

Comparably, the toothpastes were more effective than the aqueous and ethanol extracts of both chewing sticks on all bacterial isolates (based on mean zone of inhibition), except for Close up which had no inhibitory effect against $E$. coli. This agrees with the previous study by Sarmad, (2013) who concluded that toothpastes were more effective in inhibiting cariogenic and pathogenic bacteria than S. persica. However, this is contrary to the result obtained by Odeleye et al., (2016) who concluded that toothpastes had weaker antimicrobial properties than chewing sticks, on his work on the antibacterial activity of Macleans and Close up in comparison to some chewing sticks, including $M$. acuminata.

\section{CONCLUSION}

The finding suggests that the ethanol extracts of both chewing sticks ( $S$. persica and $M$. acuminata) as well as the two different toothpastes (Close up and Oral-B) have an inhibitory effect on all tested isolates, with the exception of Close up which had no inhibitory effect against $E$. coli. Advocacy should be planned to increase the use of chewing sticks based on the evidence of the current trial, especially in the developing countries with lack of funds and confined oral health care services for the general population. Also, measures should be put in place to thoroughly check for the efficacy of all the toothpastes sold within the country to ensure they are all effective against pathogenic oral bacteria. However, this research was an invitro test; therefore, further research needs to be conducted on the in-vivo efficacy of these toothpastes and chewing sticks in managing bacterial load in the oral cavity, to determine the detrimental effects of toothpastes and chewing sticks on beneficial oral bacteria. In addition, further studies should be conducted to determine the time interval of the inhibitory effect of 
the toothpastes and chewing sticks on oral pathogens, since not all bacteria found in the oral cavity are pathogenic.

\section{REFERENCES}

Al-Bayati, F. A. and Sulaiman, K. D. (2018). In vitro antimicrobial activity of Salvadora persica extracts against some isolated oral pathogens in Iraq. Turkey Journal of Biology.32:57-62.

Al-Koubaisi, F. H. (2001). The Effect of Alcoholic Extraction of Salvadora persica (Miswak) on Dental Plaque Formation a 5-day Clinical trial. Journal of Medical Sciences, Thesis, University of, Iraq, 1-50 Baghdad.

Al-Lafi, T. and Ababneh, H. (1995). The effect of the extract of miswak (chewing sticks) of the Jordan and the Middle East on oral bacteria. International Dental Journal, 45: 218222.

American Dental Association (2010) Description of Toothpaste "Toothpaste"

Anyiam, I. V., Uzor B. C. Ahuocha, P. A., and Dike, K. S. (2016). Antibacterial Properties of Chewing Stick on Bacteria Isolated from the Mouth of Individuals in Amaigbo, Imo State. International Journal of Basic Science and Technology 2(1): 71-75.

Cockerill, F. R. and Franklin R. (2012). Methods for Dilution Antimicrobial Susceptibility Tests for Bacteria That Grow Aerobically; Approved Standard- Ninth Edition. CLSI. p. 12.

Ekstrand, K. R. (2016). High Fluoride Dentrifices for elderly and vulnerable adults: Does it work and if so, Then why/Caries Research, 50(1):15-21.

Hujoel, P. P., Cunha-Cruz, J. de Oliveira, B. H. and Nadanovsky P. (2019). Fluoride Varnish and Dental Caries in Preschoolers: A Systematic Review and Meta-Analysis. Caries Research Journal, 53: 502-513.

Josephs, G. C. and Moses-Otutu, I. M. (2016). Evaluation of the antimicrobial activity of some commonly used toothpastes against selected microorganisms. Annals of Biomedical Science; 15(2): 582-7.

Marsh, P. D. and Devine, D. A. (2011). "How is the development of dental biofilms influenced by the host?." Journal of Clinical Periodontology; 38(11):28-35.

Moses, J., Rangeeth B. N. and Gurunathan, D. (2011). Prevalence of dental caries, socioeconomic status and treatment needs among 5 to 15 -year-old school going children of Chidambaram. Journal of Clinical Diagnostic Research, 5(1):146-151.

National Library of Medicine, (2014). Toothpaste overdose. National institute of Health.

Naziru, D., Muhammed, Y., Abdulrazak, A., Rabiu, S. S., Mohammed, T. B. and Aisha, A. U. (2015). Comparative antibacterial activity of chewing sticks and toothpastes commonly used in Kano (Nigeria) on clinical isolates of Staphylococcus and Streptococcus species. International Journal of Renovation and Scientific Research; 18(1): 18-25.

Odeleye, O. F., Okunye, O. L., Kesi, C. and Abatan, T. O. (2016). A study of the anticaries activity of three common chewing sticks and two brands of toothpastes in South West Nigeria. Journal of Pharmaceutical Research International, 11(5): 1-7.

Panati, C. (2013). Extraordinary Origins of Everyday Things. HarperCollins. pp. 208-209. ISBN978-06-227708-4s 
Rao, K. N. and Venhatahalan, S. R. (2000). Inhibition of dihydrofolate reductase and cell growth activity by the phenathroinidolizidine: the invitro cytotoxicity of these plants alkaloids and their potential as antimicrobial and anticancer agents. Toxicology Invitro Journal; 14:53-59.

Riley, P. and Lamont, T. (2013). Triclosan/ copolymer containing toothpastes for oral health. The Cochrane Database of Systematic Reviews (12):CD010514.

Sarmad, G. M. (2013). Comparative study of invitro antimicrobial activity of miswak extracts and different toothpastes. American Journal of Agricultural and Biological Sciences; 8(1):82-88.

Shetty, R. M., Shetty, S., Sachin, B. M., Amirisetty, R. and Agrawal, A. (2010). A comparative study to assess the effect of chewing sticks and toothbrush on oral hygiene and periodontal status among Indian population. International Journal of Public Health and Dentistry, 1:6-12.

Silk, H. (2014). "Disease of the mouth". Primary care: Clinics in Office Practice; 41(1):7590.

Sony, H., Sharma, S., Patel, S. S., Mishra, K. and Shingai, A. K. (2011). Preliminary phytochemical screening and HPLC analysis of flavonoid from methanolic extract leaves of Annona squamosal. International Research Journal of pharmacy; 5: 242-246.

Sudhir, R. V., Husam, S., Ahmed, S., Salim, A. F., Vijay, D., Eiyas, A. M. and Ahmad, A. R. (2018). The antiplaque efficacy of herebal toothpastes: a clinical intervention. Journal of International Socety of Preventive \& Community Dentistry; 8(1): 21-27.

Thilagavathi, T., Arvindganth, R., Vidhya, D. and Dhivya, R. (2015). Preliminary phytochemical analysis of Clerodendrum inereme. International Research Journal of Pharmacy; 6(2): 169-172.

Tonetti, M. S., Eickholz, P., Loos, B. G., Papapanou, P., Vander, V. U. and Armitage, G. (2015). "Principles in prevention of periodontal diseases: Consensus report of group 1 of the $11^{\text {th }}$ European Workshop on periodontology of periodontal and peri-implant diseases". Journal of Clinical Periodontology; 42(16):5-11.

Verkaik, M. J., Busscher, H. J., Jager, D., Slomp, A. M., Abbas, F. and Mei, H. C. (2011). "Efficacy of natural antimicrobials in toothpasre formulations against oral biofilms in vitro". Journal of Dentistry; 39(3): 218-24.

Walsh, T., Worthington, H. V. and Glenny, A. M. (2019). Flouride toothpastes of different concentrations for preventing dental caries in children and adolescents. Cochrane Database. 3:CD007868

Zheng, J., Quin, L. and Hai-Yang, Y. (2013). Dental Biotribiology. Springer. pp. 18-19. ISBN 978-1-4614-4550-0. 